\title{
Isolation and characterization of eleven polymorphic microsatellite markers from the beneficial carabid beetle, Poecilus cupreus (Coleoptera: Carabidae), and genetic structuring among three populations from western France
}

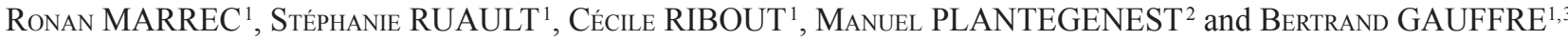 \\ ${ }^{1}$ CNRS - Université de La Rochelle, UMR 7372 CEBC, F-79360 Villiers en Bois, France; e-mails: ronanmarrec@yahoo.fr; \\ stephanie.ruault@cebc.cnrs.fr; cecile.ribout@cebc.cnrs.fr; bertrand.gauffre@cebc.cnrs.fr \\ ${ }^{2}$ INRA - Agrocampus Ouest, UMR 1349 IGEPP, F-35653 Le Rheu, France; e-mail: plantage@agrocampus-ouest.fr \\ ${ }^{3}$ INRA, USC1339 CEBC, F-79360 Villiers en Bois, France
}

Key words. Coleoptera, Carabidae, microsatellite, Poecilus cupreus, gene flow

\begin{abstract}
Poecilus cupreus (L.) (Coleoptera: Carabidae) is a typical polyphagous predator species on arable lands. In this study, 11 polymorphic microsatellite markers were developed from genomic DNA of $P$. cupreus. Genotypes of 87 individuals sampled from three localities in Western France were analyzed to characterize the polymorphism at each locus. The number of alleles ranged from 3 to 20. All pairs of loci were in linkage equilibrium. The expected and observed heterozygosity ranged from 0.165 to 0.890 and 0.103 to 0.926, respectively. From the northern to the southern sites, six, three, and six loci showed significant deviations from Hardy-Weinberg equilibrium, respectively. At one locus, null alleles were suspected as occuring at high frequency in the three populations. A weak genetic differentiation among populations was found, suggesting intense and large scale gene flow coupled with large population size in $P$. cupreus. These polymorphic microsatellite markers could be used in future population genetics studies of $P$. cupreus.
\end{abstract}

\section{INTRODUCTION}

Carabid beetles living within agroecosystems are considered as potential natural enemies of many crop pests and may provide important and valuable ecosystem services as predators of a range of arthropods, for example, aphids (Losey \& Vaughan, 2006). Altogether, the mosaic of habitat patches constituting agricultural landscapes and the crop management practices affect carabid beetle abundance and population dynamics (Holland \& Luff, 2000). This spatio-temporal heterogeneity of agricultural landscapes makes dispersal crucial for long-term survival of carabid species and for their effectiveness as natural enemies of crop pests. Both depend on their ability to colonize fields from overwintering sites and on movement (both terrestrial and aerial) from one field to another. While many studies have investigated landscape influences on the level of genetic diversity and gene flow in species associated to semi-natural habitats, such as forests (Brouat et al., 2003; Keller et al., 2005; Matern et al., 2009; Lagisz et al., 2010; Gaublomme et al., 2013) or grasslands (Sander et al., 2006a, b), to date, very few studies have sought to address this issue for common species within arable landscapes (but see Marchi et al., 2013).

The ground beetle, Poecilus cupreus (Linnaeus, 1758) (Coleoptera: Carabidae) is a typical polyphagous predator species commonly found inhabiting arable-ecosystems throughout Europe (Jeannel, 1942; Langmaack et al., 2001). It has developed wings (Bommarco, 1998; Hendrickx et al., 2009) but it is more likely to disperse mainly by walking (Wallin, 1985; Hendrickx et al., 2009); it is also able to run up to $10.6 \mathrm{~cm} \cdot \mathrm{s}^{-1}$ at $20^{\circ} \mathrm{C}$ (Thiele, 1977). Its dispersal behavior is largely unknown. Individuals do not show high levels of movements during the spring-summer period (Skuhravy, 1957), although field occupancy differs importantly from year to year, suggesting inter-field movements (Holland et al., 2005). Ecological studies have consistently demonstrated that individuals are likely to disperse over hundreds of metres, and that landscape composition and configuration together with resource availability may be important drivers of these movements (Firle et al., 1998; Westerberg et al., 2005). Using landscape genetic approaches, it is hoped to assess how agricultural landscapes influence $P$. cupreus population spatial structuring and dispersal and ultimately, its potential for biological control of crop pests. The present study reports on 11 polymorphic microsatellite markers that may potentially be useful in future investigations of these aspects in this particular important predatory insect.

\section{MATERIAL AND METHODS}

P. cupreus was sampled in spring 2011 in three study sites in Western France located in a north-south transect more than $300 \mathrm{~km}$ apart: "Pleine-Fougères - Armorique" (PF) $\left(48^{\circ} 36^{\prime} \mathrm{N}, 1^{\circ} 32^{\prime} \mathrm{W}\right)$, "Plaine et Val de Sèvre" (PVS) $\left(46^{\circ} 23^{\prime} \mathrm{N}, 0^{\circ} 41^{\prime} \mathrm{W}\right)$ and "Vallées et Côteaux de Gascogne" (VCG) $\left(43^{\circ} 17^{\prime} \mathrm{N}, 0^{\circ} 54^{\prime} \mathrm{E}\right)$. Individuals were caught using pitfall traps filled with a trapping solution of $50 \%$ ethanol during four-day trapping sessions. Thereafter, beetles were stored in the lab in a $96^{\circ}$ ethanol solution until DNA extraction. DNA was extracted from hind leg tissues of $96 \mathrm{P.} \mathrm{cu}$ preus individuals $(\mathrm{PF}, \mathrm{n}=32 ; \mathrm{PVS}, \mathrm{n}=34 ; \mathrm{VCG}, \mathrm{n}=30)$ using a standard Chelex protocol. Microsatellite library development was based on 12 individuals from the three sites and realized by GenoScreen (Lille, France), involving Roche 454 GS-FLX Titanium pyrosequencing of enriched DNA libraries, as earlier described in Malausa et al. (2011). From a total of 357 microsatellite markers sequences, 35 were selected based on the number of repeated motifs and the size of amplified fragments. We designed pairs of primers using the Primer designer 2.0 software (Scientific and Educational Software, Arlington, MA, USA). In a first selection step, the amplification quality of the 35 loci was examined on 8 individuals from the PVS study site using agarose gel electrophoresis. PCR amplifications were performed in $10 \mu \mathrm{L}$ reaction volumes containing $2.5 \mu \mathrm{L}$ of template DNA, $5 \mu \mathrm{L}$ of MasterMix (Promega, Fitchburg, WI, USA), and $0.5 \mu \mathrm{L}$ of primer mix (10 
TABLE 1. Characterization of 11 polymorphic microsatellite loci developed for Poecilus cupreus and global diversity statistics. Locus name, NCBI SRA Sequence Accession Number (NCBI SRA Acc. No.), forward (F) and reverse (R) primer sequences, number of alleles $\left(\mathrm{N}_{\mathrm{A}}\right)$, observed heterozygosity $\left(\mathrm{H}_{\mathrm{O}}\right)$, expected heterozygosity $\left(\mathrm{H}_{\mathrm{E}}\right)$, uncorrected exact $P$-value of Hardy-Weinberg equilibrium test $(\mathrm{HWE}-P)(* *<0.01 ; * * * 0.001)$.

\begin{tabular}{|c|c|c|c|c|c|c|c|c|c|c|}
\hline \multirow{2}{*}{ Locus } & \multirow{2}{*}{$\begin{array}{l}\text { NCBI SRA } \\
\text { Acc. No. }\end{array}$} & \multirow{2}{*}{ Primer sequence (5'-3') } & \multicolumn{2}{|c|}{ Repeat Allele sizes } & \multicolumn{6}{|c|}{ Sequencing Genetic diversity $(\mathrm{n}=87)$} \\
\hline & & & motif & range & Dye & group & $\mathrm{N}_{\mathrm{A}}$ & $\mathrm{H}_{\mathrm{O}}$ & $\mathrm{H}_{\mathrm{E}}$ & HWE-P \\
\hline Pcup28 & SRR1424710.1 & $\begin{array}{l}\text { F: ATTGGTGATTGCAGTTGGCT } \\
\text { R: AAGGAATCCGGTGCATCG }\end{array}$ & $\mathrm{AC}$ & $144-176$ & VIC & $\mathrm{a}$ & 18 & 0.907 & 0.869 & ns \\
\hline Pcup40 & SRR1424710.2 & $\begin{array}{l}\text { F: TCTTAACATTAACAGACCAAGATAAC } \\
\text { R: CATTCATTCAACAAGACAGACG }\end{array}$ & AGA & $175-184$ & VIC & a & 4 & 0.310 & 0.463 & $* * *$ \\
\hline Pcup64 & SRR1424710.3 & $\begin{array}{l}\text { F: GTGATTCATTACAACCGTCTAGG } \\
\text { R: GTCCATAATAAATCGTGTAACTCG }\end{array}$ & $\mathrm{AC}$ & 191-199 & FAM & $\mathrm{b}$ & 5 & 0.195 & 0.495 & $* * *$ \\
\hline Pcup70 & SRR1424710.4 & $\begin{array}{l}\text { F: ATCTCGAGCACCTTGTATCGT } \\
\text { R: CAACTGCGAAGATGTGGATG }\end{array}$ & GT & $240-244$ & FAM & $\mathrm{b}$ & 20 & 0.655 & 0.669 & ns \\
\hline Pcup81 & SRR1424710.5 & $\begin{array}{c}\text { F: TCGATCTCGAGCTTCTCCTG } \\
\text { R: AATGCTTATGAGTGACTTATGATTGA }\end{array}$ & $\mathrm{AC}$ & $116-126$ & PET & $\mathrm{b}$ & 6 & 0.194 & 0.521 & $* * *$ \\
\hline Pcup85 & SRR1424710.6 & $\begin{array}{l}\text { F: TGTATGCAATAACAGGACGCT } \\
\text { R: CACGCTCGGTTCTGTTATCTC }\end{array}$ & $\mathrm{CA}$ & $191-205$ & NED & $\mathrm{c}$ & 6 & 0.372 & 0.623 & $* * *$ \\
\hline Pcup86 & SRR1424710.7 & $\begin{array}{l}\text { F: TATATCAACACGAGCGCGAG } \\
\text { R: CCAGCGGCTACTTTGATCC }\end{array}$ & TG & $145-189$ & VIC & $\mathrm{c}$ & 14 & 0.750 & 0.819 & ns \\
\hline Pcup91 & SRR1424710.8 & $\begin{array}{l}\text { F: AACAAAGGCACGCAGCATC } \\
\text { R: AGCGCGGTGTGGTAATGAC }\end{array}$ & TG & $169-181$ & NED & $\mathrm{c}$ & 7 & 0.678 & 0.804 & $* *$ \\
\hline Pcup99 & SRR1424710.9 & $\begin{array}{c}\text { F: CTACAACCGTGGCGCATC } \\
\text { R: GACAATCAGGTAGCTCTACGTGG }\end{array}$ & $\mathrm{CA}$ & $154-174$ & FAM & $\mathrm{c}$ & 10 & 0.701 & 0.678 & ns \\
\hline Pcup102 & SRR1424710.10 & $\begin{array}{c}\text { F: AGAGTTAGCAACTCGGCCAT } \\
\text { R: CCTCTGTCAGTAATTATTCGTTCG }\end{array}$ & GAA & $177-186$ & NED & $\mathrm{d}$ & 4 & 0.174 & 0.263 & $* * *$ \\
\hline Pcup106 & SRR1424710.11 & $\begin{array}{l}\text { F: TGATGTGAACTAACCTGCTGTTG } \\
\text { R: GGAGACGAAGAGTTCGATATCC }\end{array}$ & TTG & $107-113$ & PET & d & 3 & 0.471 & 0.475 & ns \\
\hline
\end{tabular}

$\mu \mathrm{M}$ of forward and reverse primers). PCR amplification was performed using a denaturation step for $10 \mathrm{~min}$ at $95^{\circ} \mathrm{C}$, followed by 7 cycles of $30 \mathrm{~s}$ at $95^{\circ} \mathrm{C}, 30 \mathrm{~s}$ at $62^{\circ} \mathrm{C}$ with a decrease of $1^{\circ} \mathrm{C}$ per cycle, $30 \mathrm{~s}$ at $72^{\circ} \mathrm{C}$, then by 30 cycles of $30 \mathrm{~s}$ at $95^{\circ} \mathrm{C}, 30 \mathrm{~s}$ at $55^{\circ} \mathrm{C}, 30 \mathrm{~s}$ at $72^{\circ} \mathrm{C}, 8$ cycles of $30 \mathrm{~s}$ at $95^{\circ} \mathrm{C}, 30 \mathrm{~s}$ at $56^{\circ} \mathrm{C}, 30 \mathrm{~s}$ at $72^{\circ} \mathrm{C}$, and with a final extension step for $6 \mathrm{~min}$ at $72^{\circ} \mathrm{C}$. Fourteen loci provided good quality and apparent polymorphic amplification products while the 21 other loci appeared unsuitable due to ambiguous PCR products or failed reactions. In a second step, the forward primer of each of the 14 loci was 5 '-end-labelled with a fluorescent dye (FAM, HEX, NED or PET). The type of dye was chosen in order to simultaneously analyze loci of similar allele size and to avoid overlapping between loci with the same dye. The suite of 14 loci was amplified (following the same PCR conditions as above) and sequenced using the 96 individuals originating from the aforementioned three study sites. PCR products were diluted 1:60 before sequencing, and mixed with Formamide and a LIZ 500 size standard included (Applied Biosystems, Carlsbad, CA, USA). Fragments were separated using an Applied Biosystems 3730XL DNA Analyzer. Alleles were scored using GeneMapper ${ }^{\circledR}$ v 4.0 (Applied Biosystems) and checked manually.

In each population, the number of alleles per locus was recorded and deviation from the Hardy-Weinberg equilibrium (HWE) estimated using the exact test implemented in Genepop 4.1 (Rousset, 2008), both for each locus and globally. Unbiased expected $\left(\mathrm{H}_{\mathrm{e}}, \mathrm{Nei}, 1987\right)$, observed $\left(\mathrm{H}_{\mathrm{o}}\right)$ heterozygosity and, to quantify deviation from HWE, the Weir \& Cockerham's estimate of $\mathrm{F}_{\mathrm{IS}}$ (Weir \& Cockerham, 1984), were also calculated using Genepop. We tested genotypic linkage disequilibrium for each pair of loci followed by a false discovery rate correction for multiple tests (FDR, Benjamini \& Hochberg, 1995) with a nominal confidence level of $P=0.05$. The presence of null alleles was checked with micro-checker 2.2.3 (van Oosterhout et al., 2006) by assessing whether homozygote excess was possibly due to such alleles. FreeNA (Chapuis \& Estoup, 2007) was used to estimate null allele frequencies for each locus following the Expectation Maximization (EM) algorithm of Dempster et al. (1977). Genetic differentiation among populations was tested using $\mathrm{G}$ tests with Genepop and quantified by calculating pairwise $\mathrm{F}_{\mathrm{ST}}$ over all loci following Weir \& Cockerham (1984) in Genepop and using the ENA correction method for dataset harboring null alleles implemented in FreeNA (Chapuis \& Estoup, 2007).

Cross-species amplification was tested using the selected primer set in the following beetles: Anchomenus dorsalis (Platyninae, Platynini - Pontoppidan, 1763), Nebria brevicollis (Nebriinae, Nebriini - Fabricius, 1792), Nebria salina (Nebriinae, Nebriini Fairmaire \& Laboulbene, 1854) and Pterostichus madidus (Pterostichinae, Pterostichini - Fabricius, 1775). The amplification quality of these loci was examined on eight individuals of each species from the PVS study site using agarose gel electrophoresis.

\section{RESULTS}

Amplification failed for nine individuals due to poor DNA quality upon extraction. Among the 14 loci tested, 11 were found to be polymorphic and have been duly amplified and genotyped (Table 1). These particular loci showed high levels of polymorphism with number of alleles per locus ranging from 3 to 20 $($ mean $=8.82$; Table 1$)$. After FDR correction, no linkage disequilibrium between pairs of loci was found. Mean expected $\left(\mathrm{H}_{\mathrm{E}}\right)$ and observed $\left(\mathrm{H}_{\mathrm{O}}\right)$ heterozygosities were 0.63 and $0.50,0.68$ and $0.48,0.60$ and 0.49 in PF, PVS and VCG, respectively (Table 2). Six loci showed significant deviation from HWE at the PF study site, three at PVS and four at the VCG site (Table 2). There was a significant overall deficit of heterozygotes within the three populations (HWE $P<0.0001)$ with high global $\mathrm{F}_{\text {IS }}$ values $(0.198$, 
TABLE 2. Diversity statistics of 11 loci for the three populations of Poecilus cupreus studied. Locus name, number of alleles $\left(\mathrm{N}_{\mathrm{A}}\right)$, null allele means frequencies (Null), following van Oosterhout et al. (2006) (in bold are those explaining significantly HW disequilibrium), observed heterozygosity $\left(\mathrm{H}_{\mathrm{O}}\right)$, expected heterozygosity $\left(\mathrm{H}_{\mathrm{E}}\right)$, uncorrected exact $P$-value of the Hardy-Weinberg equilibrium test $($ HWE- $P)(*<0.05 ; * *<0.01 ; * * *<0.001)$. PF: "Pleine-Fougères Armorique"; PVS: "Plaine et Val de Sèvre"; VCG: "Vallées et Côteaux de Gascogne".

\begin{tabular}{|c|c|c|c|c|c|c|c|c|c|c|c|c|c|c|c|c|c|c|}
\hline \multirow{2}{*}{ Locus } & \multicolumn{6}{|c|}{$\mathrm{PF}(\mathrm{n}=31)$} & \multicolumn{6}{|c|}{$\operatorname{PVS}(n=29)$} & \multicolumn{6}{|c|}{$\operatorname{VCG}(n=27)$} \\
\hline & $\mathrm{N}_{\mathrm{A}}$ & Null & $\mathrm{H}_{\mathrm{O}}$ & $\mathrm{H}_{\mathrm{E}}$ & $\mathrm{F}_{\text {IS }}$ & HWE- $P$ & $\mathrm{~N}_{\mathrm{A}}$ & Null & $\mathrm{H}_{\mathrm{O}}$ & $\mathrm{H}_{\mathrm{E}}$ & $\mathrm{F}_{\mathrm{IS}}$ & HWE- $P$ & $\mathrm{~N}_{\mathrm{A}}$ & Null & $\mathrm{H}_{\mathrm{O}}$ & $\mathrm{H}_{\mathrm{E}}$ & $\mathrm{F}_{\mathrm{IS}}$ & HWE- $P$ \\
\hline Pcup28 & 12 & 0.301 & 0.903 & 0.866 & -0.044 & ns & 15 & 0.970 & 0.893 & 0.890 & -0.004 & ns & 13 & 0.546 & 0.926 & 0.866 & -0.071 & ns \\
\hline Pcup40 & 3 & 0.162 & 0.323 & 0.529 & 0.395 & $* *$ & 4 & 0.826 & 0.276 & 0.355 & 0.226 & ns & 4 & 0.130 & 0.333 & 0.496 & 0.331 & $*$ \\
\hline Pcup64 & 3 & 0.254 & 0.226 & 0.514 & 0.564 & $* * *$ & 4 & 0.351 & 0.103 & 0.528 & 0.807 & $* * *$ & 4 & 0.186 & 0.259 & 0.428 & 0.398 & $*$ \\
\hline Pcup70 & 15 & 0.954 & 0.774 & 0.783 & 0.012 & $\mathrm{~ns}$ & 11 & 0.101 & 0.655 & 0.582 & -0.128 & ns & 11 & 0.967 & 0.519 & 0.614 & 0.158 & $\mathrm{~ns}$ \\
\hline Pcup81 & 6 & 0.275 & 0.214 & 0.584 & 0.637 & $* * *$ & 5 & 0.235 & 0.154 & 0.399 & 0.619 & $* * *$ & 4 & 0.262 & 0.222 & 0.576 & 0.621 & $* * *$ \\
\hline Pcup85 & 5 & 0.136 & 0.419 & 0.581 & 0.282 & $*$ & 4 & 0.135 & 0.483 & 0.673 & 0.287 & $* *$ & 5 & 0.301 & 0.185 & 0.577 & 0.684 & $* * *$ \\
\hline Pcup86 & 12 & 0.103 & 0.807 & 0.829 & 0.027 & ns & 8 & 0.805 & 0.667 & 0.804 & 0.173 & $\mathrm{~ns}$ & 9 & 0.257 & 0.769 & 0.820 & 0.063 & ns \\
\hline Pcup91 & 6 & 0.156 & 0.516 & 0.784 & 0.346 & $* *$ & 7 & 0.487 & 0.724 & 0.807 & 0.104 & ns & 6 & 0.220 & 0.815 & 0.805 & -0.012 & ns \\
\hline Pcup99 & 10 & 0.853 & 0.807 & 0.728 & -0.110 & $\mathrm{~ns}$ & 8 & 0.400 & 0.690 & 0.713 & 0.033 & $\mathrm{~ns}$ & 7 & 0.100 & 0.593 & 0.588 & -0.009 & ns \\
\hline Pcup102 & 4 & 0.197 & 0.133 & 0.301 & 0.561 & $* * *$ & 4 & 0.879 & 0.172 & 0.165 & -0.049 & ns & 3 & 0.118 & 0.222 & 0.324 & 0.319 & ns \\
\hline Pcup106 & 3 & 0.168 & 0.419 & 0.420 & 0.003 & $\mathrm{~ns}$ & 3 & 0.580 & 0.483 & 0.503 & 0.042 & $\mathrm{~ns}$ & 3 & 0.300 & 0.519 & 0.511 & -0.015 & $\mathrm{~ns}$ \\
\hline
\end{tabular}

0.175 and 0.179 in PF, PVS and VCG, respectively). Null alleles were estimated as present in five, three and three loci at sites PF, PVS and VCG, respectively (details in Table 2). However, at one locus only (Pcup81), null alleles were suspected to occur at high frequency in all three populations. There was no differences in allelic frequencies between pairs of populations $(P>0.05)$ except between populations at PVS and VCG $(P=0.027)$. Inter-population $\mathrm{F}_{\mathrm{ST}}$ values were low, ranging from zero to 0.0045 and from zero to 0.0099 when computed using the ENA correction method for null alleles (Table 3). Cross-species amplification tests resulted in very low success of amplification in all species tested (data not shown). Hence, the 11 markers presented in this study appear not to be suitable for population genetic studies on other closely related beetle species.

TABLE 3. Pairwise $F_{S T}$ values between the three populations studied; not corrected, below diagonal, and corrected, using the ENA correction method, above diagonal. PF: "Pleine-Fougères Armorique"; PVS: "Plaine et Val de Sèvre"; VCG: "Vallées et Côteaux de Gascogne".

\begin{tabular}{cccc}
\hline & PF & PVS & VCG \\
\hline PF & - & 0.010 & 0 \\
PVS & 0.005 & - & 0.006 \\
VCG & 0 & 0.003 & - \\
\hline
\end{tabular}

\section{DISCUSSION}

In this study, eleven polymorphic microsatellite markers were developed for the carabid beetle, P. cupreus. These markers are potentially very useful in studies to elucidate the population genetic structure and gene flow of this beetle in relation to landscape features, more especially in a species for which such information is presently unavailable.

Despite optimization efforts, null alleles were detected at some microsatellite loci tested. Because of the likelihood of underestimating heterozygosity, care should of course be taken when using loci potentially having null alleles in analyses, although methods do allow for their inclusion in several estimators of genetic parameters (e.g. van Oosterhout et al., 2004; Chapuis \& Estoup, 2007). The weak genetic differentiation among populations separated by distances up to $700 \mathrm{~km}$ suggests intense and large scale gene flow coupled with large population size in $P$. cupreus, and certainly, additional populations should be examined to determine the large scale spatial genetic structure of the beetle, although the present results do not impede smaller scale landscape genetic studies for this species. Excess of homozygotes measured in the three study sites might also be a result of inbreeding and local population structure.

The unsuccessful cross-species amplification is not surprising since the markers were only tested on species of other beetle genera, which decreases the chance to success in amplification. In coleopteran species, even congeneric cross-amplifications often tend to fail (Gaublomme et al., 2003; Rutkowski et al., 2011; but see Wilson et al., 2004 and Marcus et al., 2013).

ACKNOWLEDGEMENTS. We thank C. Poncet and L. Jaffrelo from the INRA Plateforme Gentyane, France (www6.clermont. inra.fr/umr1095/Equipes/Plates-formes-techniques-et-experimentales/Genotypage-a-haut-debit), for their help; C. Ribout and S. Ruault for their technical collaboration; N. Guillon, L. Mieuzet and S. Delaunay for their technical assistance; A. Vialatte for sampling coordination at the VCG study site; and H. Loxdale for his helpful editorial suggestions on the manuscript. This work is part of the Landscaphid project and was supported by the ANR Systerra program (French National Research Agency, ANR-09STRA-05). R. Marrec was supported by a French Région PoitouCharentes-Département des Deux-Sèvres PhD grant.

\section{REFERENCES}

Benjamini Y. \& Hochberg Y. 1995: Controlling the false discovery rate: a practical and powerful approach to multiple testing. - J. R. Stat. Soc. (B) 57: 289-300.

BOMMARCo R. 1998: Reproduction and energy reserves of a predatory carabid beetle relative to agroecosystem complexity. Ecol. Appl. 8: 846-853.

Brouat C., Sennedot F., Audiot P., Leblois R. \& Rasplus J.Y. 2003: Fine-scale genetic structure of two carabid species with contrasted levels of habitat specialization. - Mol. Ecol. 12: 1731-1745.

Chapuis M.P. \& Estoup A. 2007: Microsatellite null alleles and estimation of population differentiation. - Mol. Biol. Evol. 24: 621-631.

Dempster A.P., Laird N.M. \& Rubin D.B. 1977: Maximum likelihood from incomplete data via the EM algorithm. - J. R. Stat. Soc. 39: 1-38. 
Firle S., Bommarco R., Eкbom B. \& Natiello M. 1998: The influence of movement and resting behavior on the range of three carabid beetles. - Ecology 79: 2113-2122.

Gaublomme E., Dhuyvetter H., Verdyck P., Mondor-Genson G., Rasplus J.-Y. \& Desender K. 2003: Isolation and characterization of microsatellite loci in the ground beetle Carabus problematicus (Coleoptera, Carabidae). - Mol. Ecol. Notes 3 : 341-343.

Gaublomme E., Maebe K., van Doninck K., Dhuyvetter H., L X., Desender K. \& Hendrickx F. 2013: Loss of genetic diversity and increased genetic structuring in response to forest area reduction in a ground dwelling insect: a case study of the flightless carabid beetle Carabus problematicus (Coleoptera, Carabidae). - Insect Cons. Div. 6: 473-482.

Hendrickx F., Maelfait J.P., Desender K., Aviron S., Bailey D., Diekotter T., Lens L., Liira J., Schweiger O. \& Speelmans M. 2009: Pervasive effects of dispersal limitation on within-and among-community species richness in agricultural landscapes. - Global Ecol. Biogeogr. 18: 607-616.

Holland J.M. \& LufF M.L. 2000: The effects of agricultural practices on Carabidae in temperate agroecosystems. - Integr. Pest Manag. Rev. 5: 109-129.

Holland J.M., Thomas C.F.G., Birkett T., Southway S. \& OAten H. 2005: Farm-scale spatiotemporal dynamics of predatory beetles in arable crops. - J Appl. Ecol. 42: 1140-1152.

JeAnNel R. 1942: Coléoptères Carabiques (2e partie). Faune de France 40. Lechevalier, Paris, 600 pp.

Keller I., Excoffier L. \& Largiader C.R. 2005: Estimation of effective population size and detection of a recent population decline coinciding with habitat fragmentation in a ground beetle. - J. Evol. Biol. 18: 90-100.

Lagisz M., WolfF K., SAnderson R.A. \& Laskowski R. 2010: Genetic population structure of the ground beetle, Pterostichus oblongopunctatus, inhabiting a fragmented and polluted landscape: Evidence for sex-biased dispersal. - J. Insect Sci. 10: 105.

LANGMAack M., LAND S. \& Buchs W. 2001: Effects of different field management systems on the carabid coenosis in oil seed rape with special respect to ecology and nutritional status of predacious Poecilus cupreus L. (Col., Carabidae). - J. Appl. Entomol. 125: 313-320.

Losey J.E. \& VAughan M. 2006: The economic value of ecological services provided by insects. - BioScience 56: 311-323.

Malausa T., Gilles A., Meglécz E., Blanquart H., Duthoy S., Costedoat C., Dubut V., Pech N., Castagnone-Sereno P. \& DÉLYE C. 2011: High-throughput microsatellite isolation through 454 GS-FLX Titanium pyrosequencing of enriched DNA libraries. - Mol. Ecol. Res. 11: 638-644.

Marchi C., Andersen L.W. \& Loeschcke V. 2013: Effects of land management strategies on the dispersal pattern of a beneficial arthropod. — PloS One 8: e66208.
Marcus T., Assmann T., Durka W. \& Drees C. 2013: A suite of multiplexed microsatellite loci for the ground beetle Abax parallelepipedus (Piller and Mitterpacher, 1783) (Coleoptera, Carabidae). - Conserv. Genet. Resour. 5: 1151-1156.

Matern A., Desender K., Drees C., Gaublomme E., Paill W. \& Assmann T. 2009: Genetic diversity and population structure of the endangered insect species Carabus variolosus in its western distribution range: Implications for conservation. - Conserv. Genet. 10: 391-405.

NeI N. 1987: Molecular Evolutionary Genetics. Columbia University Press, New York, 512 pp.

Rousset F. 2008: Genepop'007: a complete re-implementation of the Genepop software for Windows and Linux. - Mol. Ecol. Res. 8: 103-106.

RutKowski R., SzczuKa A., Zalewski M., Korczynska J. \& GryZIAK G. 2011: Failure of microsatellite's cross-species amplification in common ground beetle Pterostichus melanarius (IIliger). - Baltic J. Coleopterol. 11: 17-24.

Sander A.C., Purtauf T., Holzhauer S.I.J. \& Wolters V. 2006a: Landscape effects on the genetic structure of the ground beetle Poecilus versicolor Sturm 1824. - Biodiv. Conserv. 15: 245259.

Sander A.C., Purtauf T., Wolters V. \& Dauber J. 2006b: Landscape genetics of the widespread ground-beetle Carabus auratus in an agricultural region. - Basic Appl. Ecol. 7: 555-564.

SkUHRAVY V. 1957: Bewegungsareal einiger Carabidenarten. Acta Soc. Entomol. Bohemoslov. 53: 171-179 [in Czech, Russian and German abstr.].

Thiele H.U. 1977: Carabid Beetles in their Environments. A Study on Habitat Selection by Adaptation in Physiology and Behaviour. Springer, Berlin, 369 pp.

van Oosterhout C., Hutchinson W.F., Wills D.P.M. \& Shipley P. 2004: Micro-checker: software for identifying and correcting genotyping errors in microsatellite data. - Mol. Ecol. Notes 4: $535-538$.

van Oosterhout C., Weetman D. \& Hutchinson W.F. 2006: Estimation and adjustment of microsatellite null alleles in nonequilibrium populations. - Mol. Ecol. Res. 6: 255-256.

WALLIN H. 1985: Spatial and temporal distribution of some abundant carabid beetles (Coleoptera: Carabidae) in cereal fields and adjacent habitats. - Pedobiologia 28: 19-34.

WeIR B.S. \& Cockerham C.C. 1984: Estimating F-statistics for the analysis of population structure. - Evolution 38: 1358 1370 .

Westerberg L., Ostman O. \& Wennergren U. 2005: Movement effects on equilibrium distributions of habitat generalists in heterogeneous landscapes. - Ecol. Model. 188: 432-447.

Wilson A.C.C., Massonnet B., Simon J.-C., Prunier-Leterme N., Dolatti L., Llewellyn K.S., Figueroa C.C., Ramirez C.C., Blackman R.L., Estoup A. \& Sunnucks P. 2004: Cross-species amplification of microsatellite loci in aphids: assessment and application. - Mol. Ecol. Notes 4: 104-109.

Received May 15, 2014; revised and accepted June 30, 2014 Prepublished online September 12, 2014 